\title{
CIRCULATION AND DIFFERENTIATION OF SCOTTISH GAMES AND SPORTS
}

\author{
Laurent Sébastien Fournier
}

\begin{abstract}
The circulation and differentiation of the Scottish games and sports through time and space offers a fine example to study the mobility, adaptation and reconstruction of traditional rituals and festivals in general. On the one hand, traditional games such as folk-football or 'handba' remain closely connected with their original spaces and still take place at special times in the traditional Scottish calendar. On the other hand, the athletic sports and competitions known as the Highland Games have followed the Scottish diaspora in the British Commonwealth and have eventually spread all around the world. While the former address only a limited audience in the original communities, the latter have become famous and address a massive audience worldwide. While folk-football and 'handba' have remained strictly local, the Highland Games have become globalised sports. There is a paradox here, because the globalisation of the Highland Games contradicts the primitive image usually associated with the Scottish Highlands. In this article, I present some data collected both in Scotland and in the United States of America in order to show the changes in the ways that the traditional Scottish games and sports are performed in their original context and abroad. I especially try to show how the Scottish identity is disconnected from any spatial references in the new context of a global circulation of ritual patterns.
\end{abstract}

Keywords: diaspora, diffusion, games, migration, Scotland, sports, United States

\section{INTRODUCTION}

In this paper I would like to take the example of games and sports to study the mobility, adaptation and reconstruction of traditional rituals and festivals in general. To this end, I do not focus on contemporary sports, which are part of the modern mass culture and are closely related to globalisation ${ }^{1}$. Instead, I study the case of some traditional games which I first observed in Scotland but which also exist in other countries and which considerably change when circulating and being adapted to new cultural contexts. These games are connected with the ritual year of the Scottish communities worldwide: they are organised once a year in a given place and constitute moments when the Scots abroad experience their 'Scottishness', which I broadly understand here as the fact of loosely claiming Scottish roots and Scottish 'culture', considering that 
in most of the cases the players do not really know much about the language and the history of this nation.

How do national games and sports change when they are exported to a new country or to a new cultural setting? What happens to them, and how does this transfer change the culture they come from? How does this example help to grasp better the general processes of diffusion and globalisation, and how does it help to understand the circulation and differentiation of rituals and festivals in general? In order to answer these questions, I first focus on the notions of diffusion and globalisation and show that they have recently become the core ideas in the study of games and sports. Second, I describe two different types of Scottish games: the Highland Games and the traditional ball games. Third, I compare the different ways in which these two types of games circulate. I eventually come back to the Highland Games example to enlighten the reader about the differences between the ways they are performed inside Scotland and abroad. Such a comparison shows that even 'national' cultures and stereotypes can dramatically change when confronted with globalisation, circulation and diffusion.

\section{DIFFUSION AND GLOBALISATION}

On the example of games and sports I first ask some questions about the processes of circulation and differentiation of rituals and festive events in general, and then proceed to show that the study of games and sports helps to get a better grasp of these general processes. By doing so, I have reassessed some of the theories concerned with the historical diffusion of Western sports, currently being discussed in France and Great Britain. ${ }^{2}$ Until now, some authors have strongly emphasised the relations between the worldwide success of sports and the history of British imperialism (Darbon 2008). According to this theory, the success of the British Empire in the 19th century would have led the colonies to adopt some of the English sports, except when the body culture of the colonised people was too different to accept them. In India, for instance, cricket has become very popular in the last two centuries, but not rugby, because the caste system has made it difficult for the players to have a close physical contact with one another. The traditional Indian body culture therefore prevented rugby from being diffused in the Indian sub-continent, while rugby was very easily spread, for instance, through South Africa and New Zealand.

Other authors have emphasised the influence of Spanish culture in America, showing how the Spanish traditional bullfights had been transformed in Mexico with regard to the Native American mythologies (Saumade 2008). From Mexico, 
this transformed Spanish culture then reached California and New Mexico, eventually fuelling rodeos and different cowboy games in the south of the United States. In a similar way, different researchers have tried to compare the ways that different sports and games have spread around the world. They have come to the conclusion that some sports - like football - have easily reached the shores of other cultures, while some others have never crossed the boundaries of their country of origin or have remained within the limits of some regions. In this respect, globalisation is an uneven process and does not concern all the different sports.

In another perspective, some studies have emphasised the standardisation of sports in the new contemporary mass culture, while some others have insisted on the new hybrid sports that have appeared at the same time. As usual, when dealing with the notions of circulation and globalisation, some scholars have put the emphasis on the homogeneity of different regional or national cultures, while some others have conceptualised modernity as a means of increasing the diversity and complexity of different cultural practices. A whole range of processes can be observed when discussing sports and globalisation. When moving from one place to another, sports can be more or less acculturated in their new contexts, after being appropriated by new players. In this acculturation process, sports can be hybridised or, on the contrary, they can remain the same if cultural imperialism is strong enough to keep them identical to what they were at their starting point. Globalisation can be viewed as a synonym for uniformity and differentiation or syncretism, which implies a careful look at the empirical data to understand how different practices are influenced by the new settings in which they develop after being separated from their original contexts.

Answers to such questions are never simple, and I would suggest that the increasing circulation of cultural motives in our globalised world involves both unification and diversification processes. This is what makes this field of studies simultaneously difficult and fascinating. But as there are no clear-cut answers to these questions, I have relied on some ethnographic data to clarify the situation.

\section{SCOTTISH HIGHLAND GAMES}

The games and sports I first focus on in this article are called 'Scottish' but they are also practised abroad, on a worldwide level, in a good number of countries. I here consider the category of Highland Games, which are the most famous among the Scottish games. These games originally refer to the Scottish Highlands, but they are played in all sorts of landscapes and places. They take place both in the mountains and on flatlands, all around the world and especially in 
Canada and in the United States, where they have been performed as early as from the middle of the 19th century by the descendants of the Scottish diaspora. As I show further on, these games keep more or less the same structure everywhere. One part of them is especially devoted to athletics, which mainly consist in throwing heavy weights, stones, hammers, and eventually, 'tossing the caber', which is often considered as the most spectacular activity in the games, using heavy trunks and throwing them for distance. ${ }^{3}$

These sports, known as 'the heavies' or 'the heavy events', are often connected in the imagery with the times when the clan chiefs had to select the strongest men for the war, or those with professional skills when work needed considerable strength, like, for instance, in woodcutting. The method of 'tossing the caber' is said to be related with the technique of throwing trees to cross rivers and bring them down in the valleys of the Scottish Highlands. Besides these sports, the Highland Games usually feature other disciplines like the tug-of-war, races, or jumping, and also traditional dancing and piping with the emblematic Scottish bagpipe. Around these different competitions, the spectators can also drink, eat, and have fun at the funfair. Throughout years, the Highland Games have become an important touristic attraction in the summer, as they globally represent the Scot-

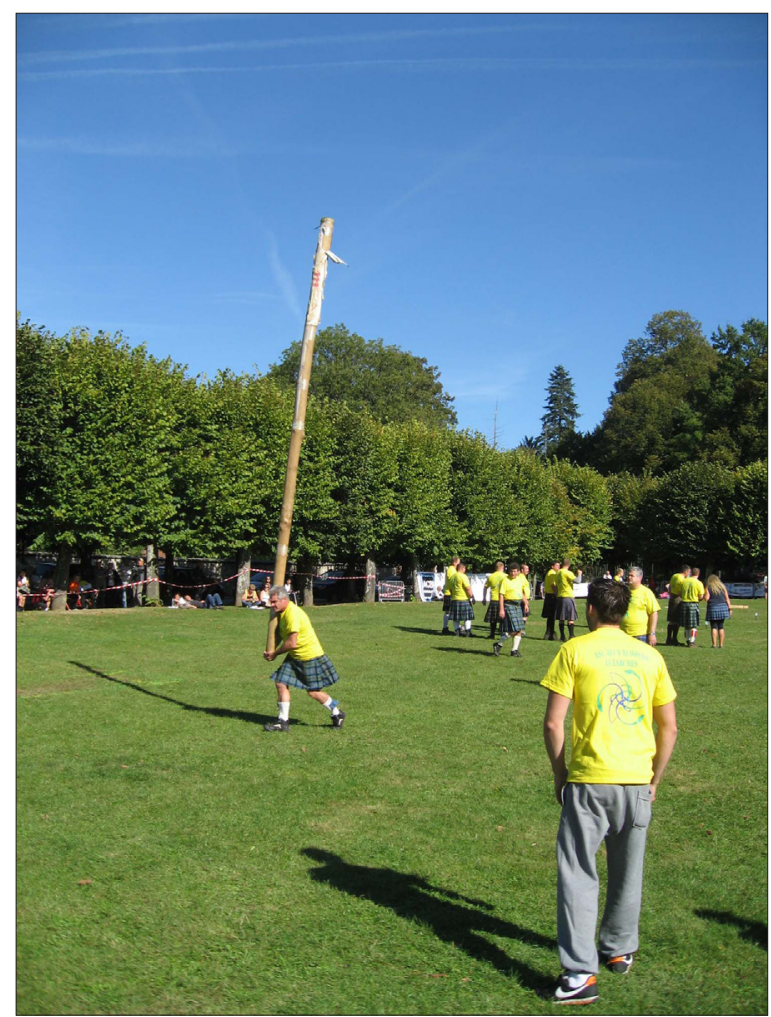
tish identity and values. This is the reason why they have been organised annually in several dozen of Scottish towns since the 19th century.

Figure 1. Caber tossing. Luzarches, France. Photograph by Laurent Sébastien Fournier 2012. 
Interestingly, the model of the Highland Games, although being presented as 'typically Scottish', has not remained in Scotland only. Already in the 19th century, the Highland Games were transferred and adapted to all the places where the Scots had emigrated. Of course, Canada and the United States have been massively concerned (Redmond 1971; 1982), but the games have also become popular in the countries of the British Commonwealth, in Australia and New Zealand, and more recently they have reached other places, such as Japan, France, the Netherlands, Germany, Hungary, the Baltic countries, etc. In all these countries, the Scottish origins of the games are clearly emphasised and athletes circulate around the places where the best stone throwers or specialists in 'caber tossing' in the world can be found. In spite of having a traditional 'Scottish' image, the contemporary Highland Games feature a truly globalised sportive event, involving special championships, prizes, and specialists. Each year, hundreds of thousands of people attend the games, which simultaneously perform different competitions and present a distinctive image of the Scottish identity.

Fieldwork in the different places where the Highland Games are organised shows that they can vary considerably, being rural or urban, bigger or smaller, more or less conservative. However, in all the places where I have attended a number of them - in Scotland, but also in France and in the United States participant observation and interviews show that they all present the same key features: heavy athletics, traditional dances, and bagpipe competitions. Moreover, there are some federations like the Scottish Highland Games Association (SHGA) or the International Highland Games Federation (IHGF), who act as powerful bodies in reinforcing the homogeneity of the games and helping the circulation of unified standards. ${ }^{4}$ Over the years, the Scottish Highland Games have become famous and have plenty of followers. They address a massive audience worldwide and are organised as modern athletic sports, often compared with track and field sports.

\section{SCOTTISH TRADITIONAL BALL GAMES}

It is interesting to compare this highly standardised Highland Games model with other forms of traditional games and sports in Scotland. Scotland has been the cradle of golf, shinty (a team game played with sticks and a ball), and curling. Golf has become a successful sport in the modern times, and some valuable analyses still need to be undertaken to understand the history of the diffusion of this sport. Yet, some traditional ball games also exist in Scotland, and below I would like to concentrate on this example. In the Scottish Borders region in 
the south, but also in the Orkney Islands up north, some villages annually play the games called folk-football or handba. These games are interesting because they are strongly connected with the traditional calendar as well as with their places of origin.

The game of folk-football or 'ba' game', as it is often called, usually takes place once a year in a special place. Nowadays it is played in less than ten places in Scotland but, according to archival records, it used to be played in more places in the past. On a fixed date, which can be Christmas in the Orkney Islands or around Shrovetide in the Borders, the villages are divided into two groups, which contest for one or several leather balls. The two groups are known as 'uppies' and 'downies' because they come from the upper and the lower parts of the villages, respectively. Some officials throw up the balls and the game - or the different sets of the game, according to the places - features a large melee which people often compare with primitive rugby. ${ }^{5}$ The melee is quite spectacular and attracts spectators, including journalists, but the game is played out of season and it is often presented as violent and dangerous, although it does not cause much damage in reality (Fournier 2013). However, the bad reputation of the game and its supposed violence lead the players to advertise it as little as possible, and therefore the game usually remains mainly local.

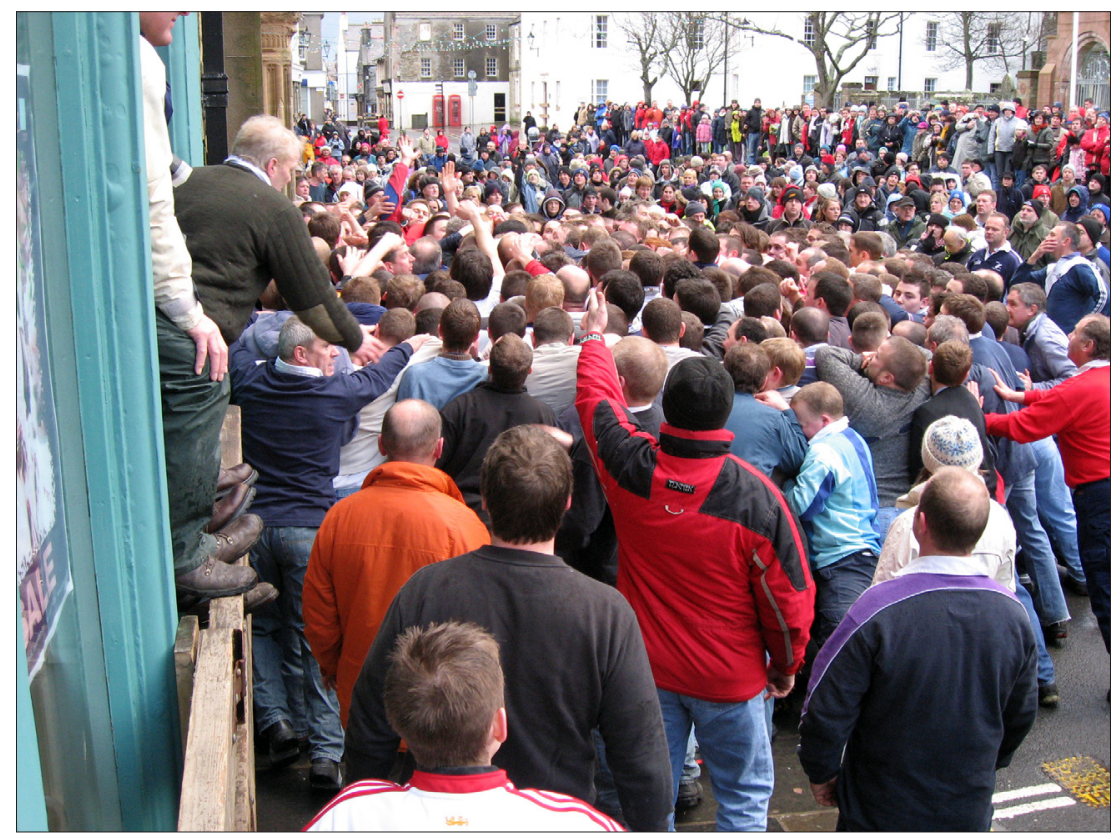

Figure 2. Folk-football. Kirkwall, Scotland. Photograph by Laurent Sébastien Fournier 2007. 


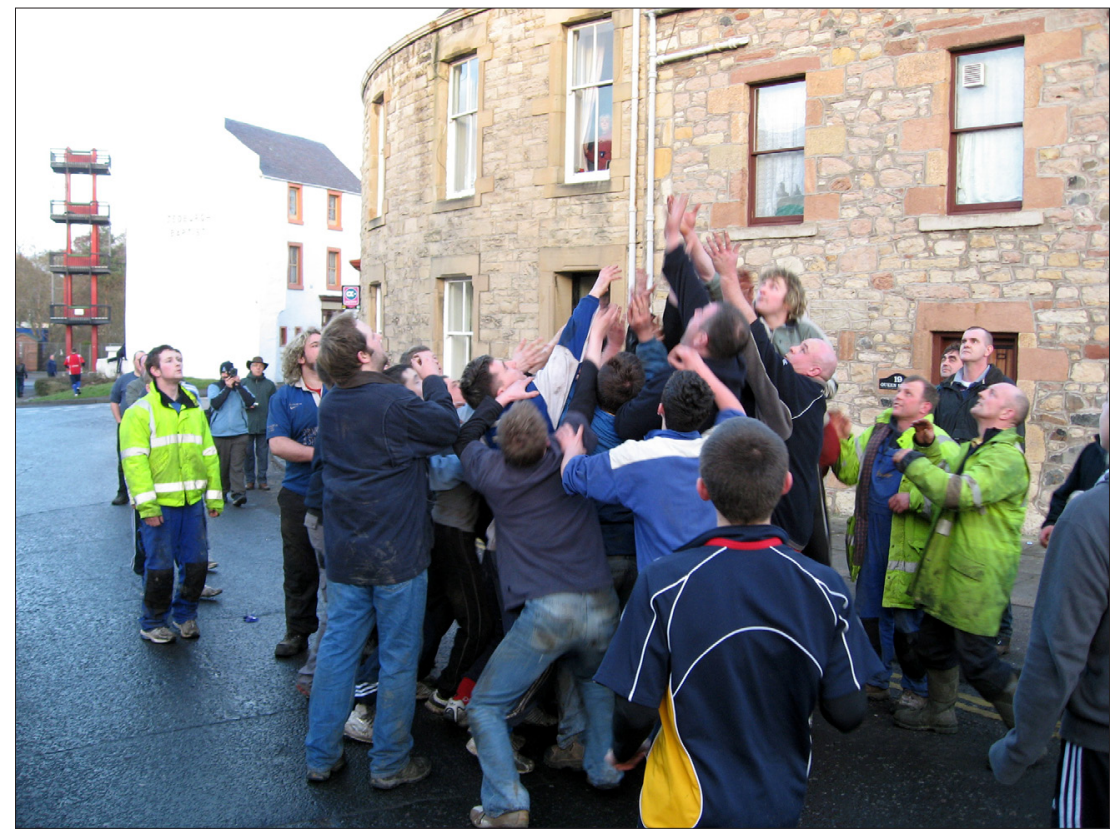

Figure 3. Handba. Jedburgh, Scotland. Photograph by Laurent Sébastien Fournier 2008.

This example is interesting as regards the question of circulation, because it has not been adapted abroad in spite of its important role in the shaping of the traditional ritual calendar of Scotland. Many people know about the game, especially in its Orcadian version, and everybody regards it as a typical local custom. However, unlike the Highland Games model, folk-football has not been exported as such, except if we consider soccer and rugby as the modern evolutions of the game. Interviews after folk-football matches showed that the locals who had emigrated sometimes came back for the game, especially in the Orkney Islands, where the game is played at Christmas, but nobody has tried to play the game abroad, except as a re-enactment in an Italian festival of traditional games in Verona, two or three years ago.

\section{DIFFERENT GAMES, DIFFERENT CIRCULATIONS}

I do not insist here on the cultural importance of the game of folk-football. In a previous article, I already suggested that in spite of its apparent roughness, the game structures are extremely complex (Fournier 2013). In her works on seasonal contests, Emily Lyle (1990) has brought evidence that this game could 
be connected with the structure of the ritual year in a larger Indo-European context.

Rather, I would like to question the contrast between the games that are easily exported, like the Scottish Highland Games, and the ones that are not. The Scottish material I have presented here shows, on the one hand, a set of games which have turned global and have followed the Scottish diaspora abroad, and, on the other hand, another set of games that have remained strictly local and only address a few thousand people in the country. At the same time, only the Highland Games explicitly claim their 'Scottishness', whereas the folk-football is said to be 'local' and 'traditional', but not especially 'Scottish'. Only the Highland Games refer to tartans and bagpipes and have a clear connection with the Scottish national stereotypes. They are also the only ones that have been commoditised for the needs of tourism industry. Some people certainly claim that folk-football is a national game because Sir Walter Scott played a role in advocating it: according to historian John Burnett (2000), he organised a match in Carterhaugh in 1815. In these games, however, the players very rarely refer to Scotland as a whole. They are much more concerned with the identity of a local town, through the opposition between the 'uppies' and 'downies', for instance, than with any claim of national identity.

This comparison eventually brings us to a paradox. The globalisation of the Highland Games contradicts the primitive image usually associated with the Scottish Highlands, and at the same time the Highland Games have become famous among strangers, for whom they represent a typical image of Scotland. It is interesting to observe that the Highland Games have been selected by strangers, as well as by the Scots abroad, as the best means of representing Scotland. In this context, there is a disconnection between the image of Scotland abroad and what is really going on in Scotland today, because abroad the image of Scotland is still orientated by the primitive Highlands, while the towns and the low country are much more valuated inside contemporary Scotland.

As it often happens in diffusion processes, the older cultural traits remain the most important outside while inside the self-image of the culture has already dramatically changed. The world still follows the 19th-century romantic images of the Scottish Highlands through the Highland Games, while new 'modern' priorities have appeared in contemporary Scotland. At the time when Scotland is seeking for national independence, it is not a real surprise to see that tartans and bagpipes are often considered old-fashioned and even ridiculous by the new Scottish creative classes (Nairn 2003 [1977]). However, these emblems are still massively used to represent Scotland in the United States or in the former British colonies. Interestingly, the new places that are willing to be identified with Scotland, in Europe or elsewhere, also use the old models instead of looking 
closer at the contemporary Scottish culture. In a way, the accepted romantic image of Scotland, as it was developed in the 19th century, is like a ghost still haunting contemporary Scotland with outdated images and stereotypes.

\section{COMPARING HIGHLAND GAMES IN SCOTLAND AND ABROAD}

It is interesting to compare in more detail the Highland Games of Scotland and the Highland Games abroad, in order to grasp their differences and to ascertain what elements have been selected and why. Attending the Highland Games in Pleasanton, California, and in Grandfather Mountain, North Carolina, is extremely instructive in this respect. ${ }^{6}$ These two Highland Games are clearly the most populous in the world, with tens of thousands of visitors every year. In spite of their obvious differences - the former occur in an urban area on the western coast and are more than a hundred years old, while the latter take place in the very heart of the Appalachians in the southeast of the country and originate in the $1950 \mathrm{~s}$ - these two events have much in common if you compare them with their Scottish counterparts.

Indeed, the organisers of the American Highland Games are usually highly respectable people, but they are rarely part of the national intelligentsia, as they can be in Scotland, for instance, in the Braemar Games where the royals themselves ritually open the ceremony. Of course, a great number of WASP representatives can be found in the American Highland Games, and the fact of claiming Scottishness in America is clearly connected with the older layers of European settlers and with a special form of establishment. Most of the Scots arrived in North Carolina in the 18th century, if not before, and some of the participants in today's games claim an uninterrupted ancestral line in the region since these times. But at the same time, in the United States, even the most powerful sponsors of the Scottish games do not have any real political or symbolic influence in the country as a whole. Scottish culture only represents one of the many minorities which form the American 'melting pot'. Even if the United States have officially acknowledged the role of Scottish culture in the building up of the country, and even if April 6th was proclaimed 'Tartan Day' by the Senate in 1998, most of the public decisions regarding the valorisation of Scottish culture in America remain purely symbolical. They address the nostalgia of a few veterans and military personnel who consider Scotland as a model of strength, courage, and military virtue, but the dominant American decision-makers and stakeholders may never have heard about Scottish culture in America. In general, the American Highland Games are considered as family events, in which folklore and entertainment take a major place. Even if 
the American Highland Games actually gather more people than the Scottish ones, it is important to remember that they only represent a minority among many others in the United States.

It is, however, interesting to examine the differences in the programmes and in the styles of different Highland Games, both in Scotland and in the United States. I have already pointed to the similarities among all the different games. The Highland Games usually feature the heavies, the tartan and bagpipe folklore, as well as the fair. But under these apparent similarities, things can happen in very different ways. First, the American Highland Games feature a few sequences that do not exist in Scotland, for example, the Kirking of the Tartans, a moment when the flags of the Scottish families are blessed by a priest before the United States anthem is played, which appears to be a purely invented tradition of the American Highland Games. ${ }^{7}$ This is also the case with the Drum Major competitions which are gaining popularity in America, especially on the western coast, but which do not really exist in Scotland.

Yet, the differences are not limited to these particular sequences. Staying outdoors in a camping and talking to people at the Grandfather Mountain Highland Games shows how the American Scots manage to hybridise and combine the Scottish culture

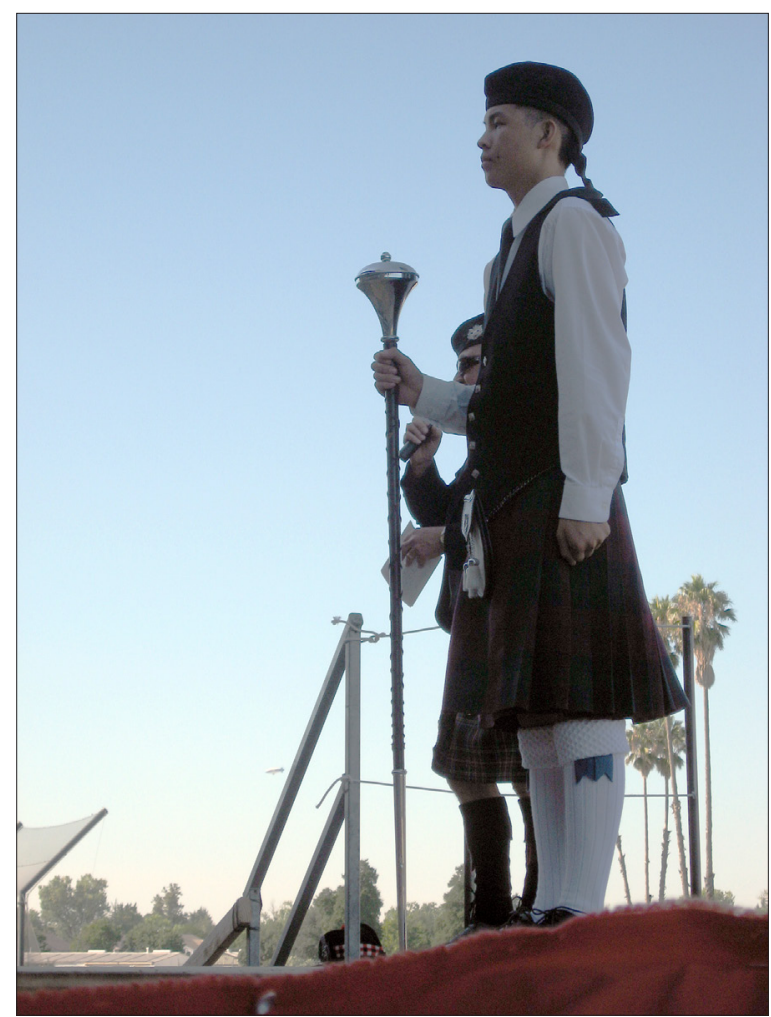
they are claiming and the Southerners' culture they are more familiar with. Indeed, most of the people here come in big RVs and look considerably more American than Scottish. Even if they wear kilts, they bring with

Figure 4. Drum major competition. Pleasanton, California. Photograph by Laurent Sébastien Fournier 2012. 
them plenty of clues concerning their American way of life. In interviews, they easily confess that they are not really Scots: some of the people I met in the American Highland Games told me they loved 'playing Scots' and liked 'everything Celtic', but most of them did not really claim any 'Scottishness'. Some of them have been involved in living history events and re-enactments before attending Scottish gatherings. When they celebrate, the 'Scottish' music they listen to often relies on heavy American references, either in the country or blues style. The American Scots are also much more preoccupied with their DNA than the Scottish Scots are. Several companies come to the games to propose DNA tests in order to trace back Scottish ancestry and reinforce the clan system which has developed in the United States in recent years. ${ }^{8}$ Last but not least, most of the campers have never been to Scotland, and the centre they take their Scottish references from is often Newfoundland, Canada, where the Highland Games existed already as early as in the middle of the 19th century.

\section{DISCONNECTED CULTURES?}

On the example of the American Highland Games, it is interesting to observe how, in the new context of a global circulation of ritual patterns and ideas, Scottish national identity manages to detach itself from its homeland and gets disconnected from any spatial references. How does this disconnection occur and how does it work?

According to the time scale that we use to analyse the circulation and differentiation of the Scottish Highland Games, we can reach different results. Looking at the process throughout history brings awareness of the sad period of the Clearances, when the Scots were forced to emigrate in the 18th century (Prebble 1966). A large number of Highlanders were then replaced by sheep on the lands of the powerful lairds. Boat registers show the importance of Scottish emigration to the United States in this period, after the disaster of the Jacobite rebellion in 1745 . It is not surprising that a number of 'Scottish societies' were founded outside Scotland by the Scots who were trying to help each other in the new hostile world. The first Scottish society was actually founded in London in the $1780 \mathrm{~s}$, but a number of similar organisations appeared in the biggest American towns in the 19th century. Some Highland Games and gatherings were already organised during this period in the United States, as historians have shown (Redmond 1971; 1982), and in some cases they have survived until today, which enables to trace their history back to the moment when they first emerged. 
The historical perspective might, however, be a tricky one when considering the gaps and changes in the American Highland Games through time. Indeed, it would be a mistake to consider the history of these games as being only linear. Most of the games that were organised in the 19th century disappeared at the beginning of the 20th century, before World War I. It is only later that some of them have been revived. According to some specialists, the geography of the games in America has dramatically changed in the past century. While the 19th century games were concentrated in Canada and in the north, many games appeared in the south of the country in the second half of the 20th century (Ray 2001). In these cases, there is no continuity at all with the historical arrival of the Scots in the United States. For most of the participants, memories of the games cover only a few years back. The ethnographic perspective is more productive here than the historical one, allowing to explore the ways the participants identify with Scotland independently from any genuine Scottish ancestry. Most of the people here invent new relations with Scotland and develop a totally free relationship with this imaginary 'motherland'.

In this context, the relations between Scotland and the United States regarding the Highland Games are very complex ones. Interestingly, these relations have evolved in both directions. Historically it is obvious that the American games were strongly influenced by the Scottish ones, as the American Scottish societies were still connected with Scotland and most of their members were born in Scotland. At one point, however, things changed. Professional sports replaced the traditional Highland Games in which amateurs predominated, and the Scottish gatherings progressively faded out. But after World War II the Highland Games were launched on a new basis. American athletes, dancers and pipers became more and more professional and started to attend the Highland Games in Scotland. A few years later they managed to win competitions and travelled more and more to different Scottish games around the world. In Scotland, on the contrary, plenty of participants were quite reluctant about the idea of going abroad and mainly remained amateurs. Most of the Scottish participants still think that the proper place for the Highland Games is Scotland, and only some of them are interested in international competitions. Today, the Scottish Highland Games Association (SHGA) runs the games inside Scotland, while the International Highland Games Federation (IHGF) promotes the games abroad. According to interviews, there are fewer and fewer Scots in the circuit, and more and more international professionals coming from America but also from different European countries. These people certainly remain very interested in Scottish culture and the moral values that Scotland is supposed to carry with the games. They are also very good athletes; they train hard and set records. In this new context, it is interesting to note that 'Scottishness' in the Scottish games and sports is no more a Scottish privilege. The internationalisation 
of the Highland Games has disconnected the Scottish culture from Scotland: international athletes proudly compete in the games, showing how a national culture can survive and develop even if being cut off from its geographical roots.

\section{CONCLUSION}

In comparison with the aforementioned, it is interesting to note that the 'remains' of traditional games still practised in Scotland, like folk-football, do not really claim any connection with 'Scottishness' or any national reference. Still practised at a local level, they have not been exported at all. Due to this, they do not need to seek for any differentiation. They just continue in a customary way, far from the modern arguments between amateurs and professionals, or between Scottish and alien versions of the games. If we consider both these examples, we eventually learn that an outside point of view is always needed to become conscious of one's identity. In the folk-football example, nobody threatens the practice of the local game by imitating it outside. The only threats come from the media and the insurance business, who consider the game as violent and risky. The Highland Games example is totally different. Here, national stereotypes are deeply challenged by their re-enactment abroad. The success of the games abroad leads to dramatic evolutions inside Scotland as well, because the stereotypes now represent much more than merely Scotland. Circulation has led to the definition of a double Scotland: a real one and an imaginary one, whereas the latter can be more competitive and more powerful than the former. This is why the idea of circulation is so important in understanding identity matters.

\section{NOTES}

1 When speaking about the globalisation of sport cultures, I use the definitions discussed and the different case studies published in France, in a recent issue of the Journal des Anthropologues (Fournier \& Raveneau 2010).

${ }^{2}$ On the diffusion of sports, see the recent thematic issue of the journal Ethnologie française (Darbon 2011).

3 See, for instance: http://www.youtube.com/watch?v=ujpfCRpqkFs, last accessed on December 10, 2014.

${ }^{4}$ Compare the websites http://www.shga.co.uk and http://www.worldheavyevents.com (both last accessed on December 11, 2014) to find out more about the different ways the Highland Games can be advertised.

5 Compare the videos of the Kirkwall game in 1939 (http://www.youtube.com/ watch?v=CDmZR11B8BQ) and in 2011 (http://www.youtube.com/watch?v=eaBi6VCGrpw) (both last accessed on December 11, 2014) to have an idea. 
6 The fieldwork was conducted in California in August 2012, and in North Carolina in July 2013, thanks to the French CNRS programme "Diffusion internationale, revitalisations et transformations sociales des jeux athlétiques traditionnels: ethnographie et comparaison des modes de pratique en Ecosse et aux Etats-Unis" (IDEMEC, UMR 7307 CNRS et Aix-Marseille Université). See also the websites of the two events: http://www.thescottishgames.com and http://www.gmhg.org (both last accessed on December 12, 2014).

7 See Hobsbawm and Ranger (1983) on the invention of the tradition. Hugh TrevorRoper's contribution to this reflection is especially relevant because it shows how the tartans were already an invented tradition in the 19th century (Trevor-Roper 2009).

8 The Council of Scottish Clans and Associations (COSCA) was founded in the United States in 1974. See: http://www.cosca.net, last accessed on February 11, 2015.

\section{REFERENCES}

Burnett, John 2000. Riot, Revelry, and Rout: Sport in Lowland Scotland Before 1860. East Linton: Tuckwell Press.

Darbon, Sébastien 2008. Diffusion des sports et impérialisme anglo-saxon. Paris: Maison des Sciences de l'Homme.

Darbon, Sébastien 2011. Introduction. La diffusion des sports: Confrontations disciplinaires et enjeux méthodologiques. Ethnologie française, Vol. 41, No. 4, pp. 581592. http://dx.doi.org/10.3917/ethn.114.0581.

Fournier, Laurent Sébastien 2013. Violence and Roughness in Traditional Games and Sports: The Case of Folk Football (England and Scotland). Folklore: Electronic Journal of Folklore, Vol. 54, pp. 39-50. http://dx.doi.org/10.7592/FEJF2013.54. fournier.

Fournier, Laurent Sébastien \& Raveneau, Gilles 2010. Anthropologie de la globalisation et cultures sportives. Journal des Anthropologues, Nos. 120-121, pp. 39-63.

Hobsbawm, Eric \& Ranger, Terence (eds.) 1983. The Invention of Traditions. Cambridge: Cambridge University Press.

Lyle, Emily 1990. Winning and Losing in Seasonal Contests. Cosmos, No. 6, pp. 161-171.

Nairn, Tom 2003 [1977]. The Break-Up of Britain: Crisis and Neo-Nationalism. Altona: Common Ground Publishing.

Prebble, John 1966. The Highland Clearances. Swindon: The History Book Club.

Ray, Celeste 2001. Highland Heritage: Scottish Americans in the American South. Charlotte: The University of North Carolina Press.

Redmond, Gerald 1971. The Caledonian Games in Nineteenth-Century America. Madison, NJ: Fairleigh Dickinson University Press.

Redmond, Gerald 1982. The Sporting Scots of Nineteenth-Century Canada. Madison, NJ: Fairleigh Dickinson University Press.

Saumade, Frédéric 2008. Maçatl : les transformations mexicaines des jeux taurins. Bordeaux: Presses Universitaires de Bordeaux.

Trevor-Roper, Hugh 2009. The Invention of Scotland: Myth and History. New Haven \& London: Yale University Press. 